\title{
Peningkatan Pengetahuan Ibu Tentang Keluarga Berencana Dalam Perspektif Keperawatan Islami Sebagai Upaya Menekan Risiko Kehamilan
}

\author{
Suko Pranowo \\ Prodi S1 Keperawatan, \\ STIKES Al-Irsyad Al-Islamiyyah, Jalan Cerme No 24 Sidanegara Cilacap 53223 \\ Email korespondensi: supra74sukopranowo@gmail.com
}

\begin{abstract}
Abstrak
Angka kematian ibu (AKI) menjadi salah satu indikator penting dari derajat kesehatan masyarakat. Pada tahun 2019 AKI di Kabupaten Cilacap masih tinggi yaitu 16 orang, AKB mencapai 145 orang. Masalah yang berkaitan dengan AKI dan AKB tidak bisa lepas dari status kesehatan ibu dan kesiapan untuk hamil, pemeriksaan antenatal, pertolongan persalinan dan perawatan segera setelah persalinan. Kehamilan dengan jarak yang terlalu dekat akan meningkatkan risiko perdarahan, keguguran, hingga kematian pasca persalinan. Salah satu upaya untuk mencegahnya yaitu dengan mengikuti program KB bagi Pasangan Usia Subur (PUS) untuk memulihkan kondisi setelah hamil sebelumnya. Di RW 14 Kelurahan Sidanegara jumlah PUS sebanyak 414 jiwa, dan jumlah akseptor KB sebanyak 338, (akseptor MKJP 104 orang dan akseptor non MKJP sebanyak 234 orang). Pengabdian kepada masyarakat ini dilakukan di RW 14 Kelurahan Sidanegara, Kecamatan Cilacap Tengah. Tujuan dari pengabdian kepada masyarakat ini adalah memberikan pemahaman kepada PUS tentang KB dalam pandangan keperawatan Islami. Diharapkan PUS dapat memahami dan akhirnya memutuskan untuk mengikuti KB dalam rangka meningkatkan kesehatan Ibu dan Anak. Setelah dilakukan pendidikan kesehatan didapatkan data bahwa terjadi peningkatan pengetahuan yang signifikan yaitu kategori baik sebelum intervensi pendidikan kesehatan sebanyak 0 orang $(0 \%)$ dan kategori baik setelah dilakukan intervensi pendidikan kesehatan sebanyak 17 orang $(94,44 \%)$. Terdapat kenaikan jumlah peserta yang memiliki pengetahuan dengan kategori baik yaitu sebanyak 17 orang. Memiliki selisih rata-rata pre dan post test nilai pengetahuan sebanyak 3,33. Diharapkan bagi PUS menjadi akseptor KB untuk mencegah risiko kehamilan dan dapat merencanakan keluarganya dengan baik.
\end{abstract}

Kata kunci: KB, perspektif, Islam

Abstract

The maternal mortality rate (MMR) is an important indicator of the degree of public health. In 2019 MMR in Cilacap Regency was still high, namely 16 people, IMR reached 145 people. Problems related to AKI and IMR cannot be separated from the mother's health status and readiness for pregnancy, antenatal checks, delivery assistance and immediate care after delivery. Pregnancy with a distance that is too close will increase the risk of bleeding, miscarriage, and postpartum death. One of the efforts to prevent this is by joining the family planning program for fertile aged couples (PUS) to restore their condition after their previous pregnancy. In RW 14, Sidanegara Village, the number of PUS is 414 people, and the number of KB acceptors is 338, (104 MKJP acceptors and 234 non-MKJP acceptors). This community service is carried out in RW 14, Sidanegara Village, Cilacap Tengah District. The purpose of this community service is to provide an understanding to PUS about family planning in the view of Islamic nursing. It is hoped that PUS can understand and finally decide to participate in family planning in order to improve maternal and child health. After the health education was carried out, data showed that there was a significant increase in knowledge, namely the good category before the health education intervention as many as 0 people (0\%) and the good category after the health education intervention as many as 17 people (94.44\%). There was an increase in the number of participants who had knowledge in good categories, namely 17 people. Has a difference in the average pre and post test knowledge score of 3.33. It is hoped that PUS will become family planning acceptors to prevent the risk of pregnancy and be able to plan their family well.

Keywords: KB, perspective, islam. 


\section{PENDAhULUAN}

Angka kematian ibu (AKI) menjadi salah satu indikator penting dari derajat kesehatan masyarakat. Pada tahun 2019 AKI Indonesia masih tetap tinggi, yaitu 305 per 100.000 kelahiran hidup, sedangkan target AKI Indonesia pada tahun 2015 adalah 102 per 100.000 kelahiran hidup. Angka Kematian Ibu di Jawa Tengah pada tahun 2013 mencapai 613 kasus, dan pada rahun 2018 terjadi 421 kasus AKI. Sementara itu, terkait Angka Kematian Bayi (AKB) juga terus mengalami penurunan. Pada tahun 2016, angka kematian bayi mencapai 5.485 kasus, hingga tahun 2018 menurun menjadi 4.481 kasus (Rismoko, 2019); (Kemenkes RI, 2019); (Susiana, 2019). Angka Kematian Ibu (AKI) dan Angka Kematian Bayi (AKB) di Kabupaten Cilacap masih tinggi. Pada tahun 2018 AKI tercatat sebanyak 22 kasus, tahun 2019 ada 16 kasus. Pada tahun 2018 AKB mencapai 132 orang, dan tahun 2019 mencapai 145 orang (Susanto, 2019)

Sekitar 25-50\% kematian wanita usia subur di negara miskin disebabkan oleh masalah kehamilan dan persalinan, dan nifas. Pada tahun 2015, WHO memperkirakan di seluruh dunia setiap tahunnya lebih dari $585.000 \mathrm{ibu}$ hamil meninggal saat hamil atau bersalin (Kemenkes RI, 2015). Masalah yang berkaitan dengan kehamilan dan persalinan, termasuk AKI dan AKB tidak dapat dilepaskan dari berbagai faktor yang mempengaruhinya, antara lain status kesehatan ibu dan kesiapan untuk hamil, pemeriksaan antenatal (masa kehamilan), pertolongan persalinan dan perawatan segera setelah persalinan, serta faktor sosial budaya (Susiana, 2019). Kehamilan dengan jarak yang terlalu dekat akan meningkatkan risiko perdarahan, keguguran, hingga kematian pasca persalinan. Wanita yang sebelumnya mengalami kehamilan normal bahkan tidak luput dari risiko ini (Utami, 2019).

Angka Kelahiran Total (TFR) stagnan selama 10 tahun terakhir. TFR masih di kisaran angka 2,4, bahkan di beberapa daerah masih 2,6 anak per perempuan. Hal ini dikarenakan Kepesertaan ber-KB (CPR) hanya meningkat 0,5 persen dalam kurun waktu 5 tahun, masih tingginya angka ASFR 14-19 tahun yaitu 48 /1.000 wanita, masih tingginya unmet need (8,5 persen), masih rendahnya peserta KB Metode Kontrasepsi Jangka Panjang /MKJP (10,6 persen). Di Provinsi Jawa Tengah prosentase unmet need tergolong masih tinggi, dan Kabupaten Cilacap berada di rangking kedua yaitu sebesar 15\% dan Contraseption Prevalens Rate (CPR) sebesar 73\%, hal ini menandakan bahwa masih banyak Pasangan Usia Subur (PUS) tidak menggunakan alat kontrasepsi (Salengke, 2019); (BKKBN, 2019).

Data dalam SDKI Tahun 2017 menunjukkan adanya kemajuan yang dicapai program keluarga berencana $(\mathrm{KB})$ dalam 5 tahun terakhir. TFR Indonesia mengalami penurunan sebanyak 0,2 poin, dari 2,6 per wanita usia subur pada SDKI Tahun 2012 menjadi 2,4 per 
wanita usia subur pada SDKI Tahun 2017. Hasil Survei Kinerja dan Akuntabilitas Pemerintah Program Kependudukan, Keluarga Berencana dan Pembangunan Keluarga (SKAP - KKBPK) tahun 2018 menunjukkan 3 (tiga) indikator capaian RENSTRA BKKBN 2015-2019 yang telah mencapai target, yaitu: pertama penurunan angka kelahiran total menjadi 2,38 per WUS usia 15-49 tahun dari target tahun 2018 sebesar 2,31 (persentase capaian 97,1\%); Kedua, penurunan angka putus pakai menjadi 25\% dari target tahun 2018 sebesar 25\% (persentase capaian 100\%) dan ketiga peningkatan penggunaan Metode Kontrasepsi Jangka Panjang (MKJP) sebesar 23,1\% dari target tahun 2018 sebesar 22,3\% (persentase capaian 103,6\%). Namun demikian masih terdapat (dua) indikator yang perlu menjadi perhatian, karena belum tercapai. Indikator tersebut yaitu pertama, peningkatan penggunaan kontrasepsi modern yang hanya mencapai 57\% dari target tahun 2018 sebesar 61,1\% dan terakhir adalah menurunkan tingkat unmet need dari $12.4 \%$ sesuai dengan tahun 2018 sebesar 10,14\%. BKKBN masih mempunyai pekerjaan yang sangat besar untuk mencapai sasaran tahun 2019 (BKKBN, 2019).

Berdasarkan data di Kabupaten Cilacap sampai bulan Nopember 2018 terdapat kematian ibu sebanyak 1 kematian Ibu. Berdasarkan data di Puskesmas Cilacap Tengah pada tahun 2016 dan 2017 masing -masing terdapat 1 kematian ibu, dan terdapat ibu hamil dengan risiko tinggi bedsarkan usia lebih dari 40 tahun. Jumlah ibu hamil sebanyak 823 ibu hamil. Risiko kematian pada ibu hamil dapat terjadi penurunan apabila setelah persalinan menggunakan alat kontrasepsi. Berdasarkan Profil Kesehatan Kabupaten Cilacap (2018) jumlah akseptor baru di Cilacap Tengah I sebanyak 825 orang, dan jumlah akseptore KB aktif sebanyak 6170 jiwa dengan cakupan sasaran program KB 69\%.

Berdasarkan data dari kader KB RW 14 Kelurahan Sidanegara jumlah Pasangan Usia Subur (PUS) sebanyak 414 jiwa, dan jumlah akseptor KB sebanyak 333. Akseptor KB IUD sebanyak 75, MOW 16, Implan 13, suntik 71, pil 28, kondom 135, dan MOP tidak ada, sehingga dapat disimpulkan bahwa jumlah akseptor MKJP 104 orang (31,2\%) dan jumlah akseptor non MKJP sebanyak 234 orang (70,3). Hasil wawancara dengan kader RW 14 dan bidan desa bahwa masih terdapat risiko kehamilan di RW 14 Sidanegara disebabkan karena masih seringnya ibu melahirkan sehingga menyebabkan jumlah balita dalam satu keluarga lebih dari dua, sehingga bisa menjadi salah satu faktor risiko pada kehamilan karena usia lebih dari 35 tahun. Berdasarkan wawancara dengan Kader, menyebutkan bahwa ada PUS yang tidak mau KB dengan alasan bahwa tujuan KB adalah membatasi keturunan, sedangkan dalam Islam dianjurkan untuk memperbanyak keturunan. Berdasarkan latar belakang permasalahan mitra, maka solusi yang ditawarkan yaitu penyuluhan tentang Metode 
Kontrasepsi Jangka Panjang (MKJP) dalam Pandangan Keperawatan Islami di Posyandu RW 14 Kelurahan Sidanegara, Cilacap Tengah.

Pengabdian kepada masyarakat ini dilakukan di RW 14 Kelurahan Sidanegara, Kecamatan Cilacap Tengah. Tujuan dari pengabdian kepada masyarakat ini adalah memberikan pemahaman kepada PUS/WUS tentang KB dalam pandangan keperawatan Islami. Diharapkan PUS/WUS dapat memahami dan akhirnya memutuskan untuk mengikuti KB dalam rangka meningkatkan kesehatan Ibu dan Anak.

\section{MASALAH}

Hasil wawancara dengan kader RW 14 dan bidan desa bahwa disebabkan karena masih seringnya ibu melahirkan sehingga menyebabkan jumlah balita dalam satu keluarga lebih dari dua, sehingga bisa menjadi salah satu faktor risiko pada kehamilan karena usia lebih dari 35 tahun. Berdasarkan wawancara dengan Kader, menyebutkan bahwa ada PUS yang tidak mau $\mathrm{KB}$ dengan alasan bahwa tujuan KB adalah membatasi keturunan, sedangkan dalam Islam dianjurkan untuk memperbanyak keturunan. Permasalahan yang terjadi di RW 14 Kelurahan Sidanegara adalah:

1) Masih rendahnya pengetahuan tentang risiko persalinan.

2) Masih rendahnya pengetahuan tentang KB dalam pandangan keperawatan Islam.

\section{METODE PELAKSANAAN}

Pendekatan yang dilakukan untuk mengatasi permasalahan yang ada di Kelurahan Sidanegara adalah perlunya dilakukan pemberian pendidikan kesehatan sebagai upaya promotive dan preventif terhadap risiko yang mungkin terjadi pada Ibu dengan menjadi akseptor KB MKJP. Sasaran pelaksanaan kegiatan adalah Ibu dengan usia produktif yang berjumlah 25 orang.

Berdasarkan identifikasi masalah yang telah dirumuskan, maka kami menawarkan solusi permasalahan melalui serangkaian kegiatan dengan melibatkan partisipasi aktif dari Ibu atau Wanita Usia Subur dan Kader RW 14 Sidanegara, sebagai berikut :

1) Persiapan

a. Melakukan koordinasi dengan pihak Puskesmas Cilacap Tengah I dan Kelurahan Sidanegara dan petugas KB untuk pemilihan Posyandu yang akan dijadikan tempat pengabdian.

b. Kriteria peserta adalah WUS dan Kader, bersedia ikuti pelatihan, memiliki waktu yang cukup dan berpartisipasi aktif dalam kegiatan kelompok 
c. Tahap persiapan dilakukan 2 hari

2) Pelaksanaan Pelatihan

Pengabdian dilaksanakan pada tanggal 4 Juli 2020 kepada masyarakat di RW 14 Sidanegara, sebanyak 18 orang.

Metode pelaksanaannya adalah sebagai berikut:

a. Pre test

Pada sesi ini dilakukan test untuk mengetahui sejauh mana pengetahuan tentang $\mathrm{KB}$ dalam perspektif keperawatan Islami.

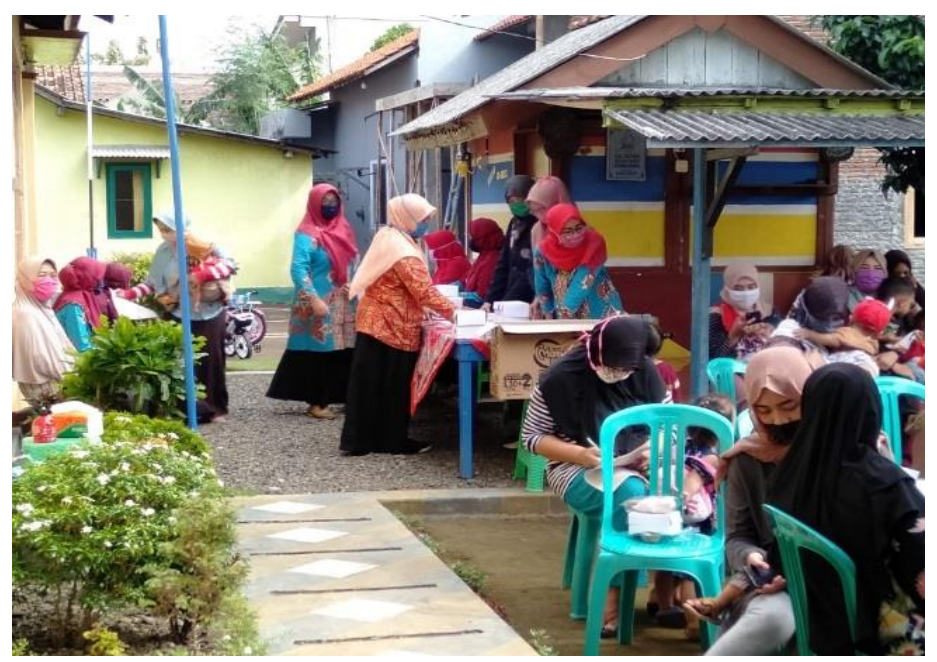

Gambar 1. Pelaksanaan Pre Test

b. Pemberian materi

Materi meliputi pengertian KB, konsep menunda dan batasi kehamilan, kondisi yang memperbolehkan KB, kondisi yang tidak memperbolehkan KB. Metode yang digunakan yaitu ceramah menggunakan media LCD, Laptop. Materi diberikan selama 30 menit.

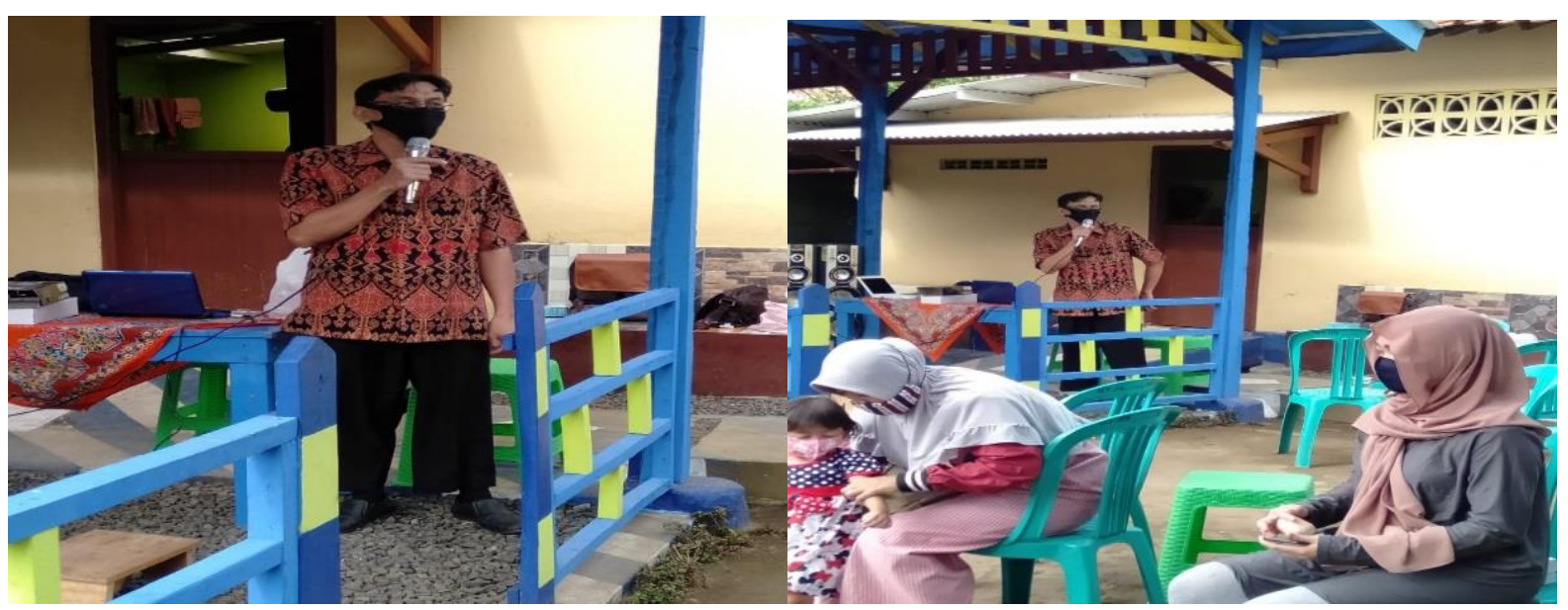

Gambar 2. Pelaksanaan Pemberian Materi

c. Post test

Tahap ini merupakan sesi untuk mengukur sejauh mana pengetahuan dipahami. 


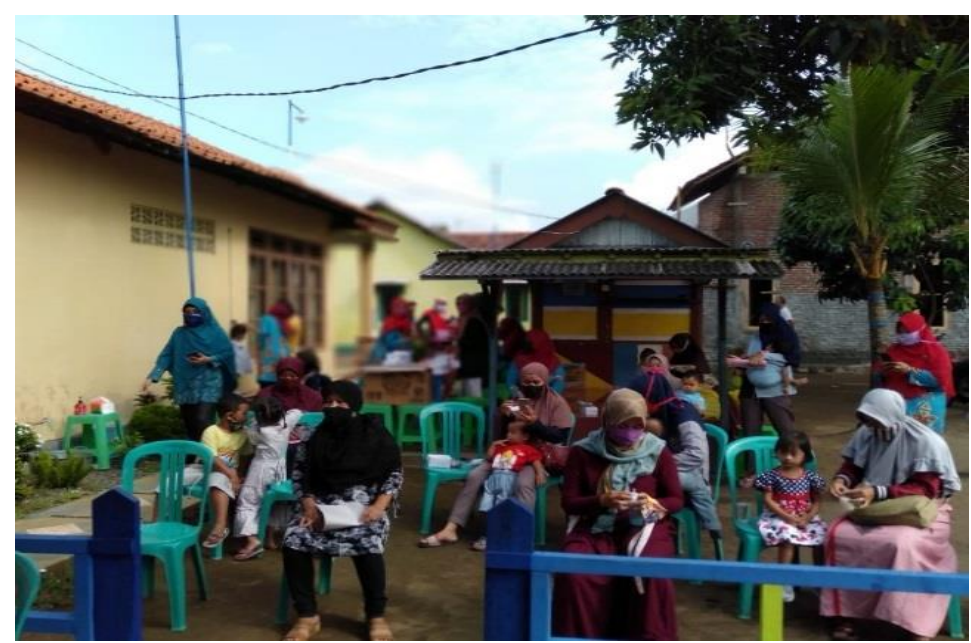

Gambar 3. Pelaksanaan Post Test

d. Tahap pelaksanaan dilakukan 1 hari

3) Monitoring dan evaluasi

Tahap ini dilakukan oleh tim pelaksana pengabdian. Tujuan dilakukan monitoring dan evaluasi adalah untuk memastikan bahwa mereka yang awalnya menolak KB karena alasan apapun menjadi terbuka dengan melihat kondisi yang ada sehingga dapat memutuskan untuk KB dalam konteks yang diperbolehkan syariat dan mengajarkan kepada penderita lain yang tidak mengikuti kegiatan ini. Selain itu perlu adanya pendataan akseptor KB baru di RW 14 Sidanegara. Tahap ini dilakukan 1 kali dalam 1 bulan dengan melakukan kunjungan Posyandu dan sasaran.

\section{HASIL DAN PEMBAHASAN}

\section{1) Hasil}

Adapun hasil penilaian kuesioner pretest dan pos test terhadap pengetahuan dan keterampilan masyarakat tentang pencegahan ulkus diabetik adalah sebagai berikut:

a. Pre Test

Tabel 1

Distribusi Frekuensi Pengetahuan Masyarakat Sebelum Diberikan Pendidikan Kesehatan tentang KB dalam Keperawatan Islami Di Kelurahan Sidanegara Kecamatan Cilacap Tengah

\begin{tabular}{|c|c|c|c|}
\hline No. & Ketrampilan & Frekuensi & Persen \\
\hline 1 & Baik & 0 & 0 \\
\hline 2 & Cukup & 8 & 44,44 \\
\hline 3 & Kurang & 10 & 55,56 \\
\hline \multicolumn{2}{|c|}{ Jumlah } & 18 & 100 \\
\hline \multicolumn{4}{|c|}{ Rata-rata Nilai $=4,50$} \\
\hline
\end{tabular}

Berdasarkan tabel 1 dapat diketahui bahwa sebelum responden diberikan Pendidikan Kesehatan tentang KB dalam keperawatan Islami paling banyak mempunyai pengetahuan 
dengan kategori kurang yaitu 10 orang $(55,56 \%)$ dan tidak ada yang mempunyai pengetahuan dengan kategori baik (0\%). Responden memiliki rata-rata nilai pengetahuan 4,50.

b. Post Test

Tabel 2

Distribusi Frekuensi Pengetahuan Masyarakat Setelah Diberikan Pendidikan Kesehatan tentang KB dalam Keperawatan Islami Di Kelurahan Sidanegara Kecamatan Cilacap Tengah

\begin{tabular}{llccc}
\hline \multicolumn{1}{c}{ No. } & & Ketrampilan & Frekuensi & Persen \\
\hline 1 & Baik & 17 & 94,44 \\
2 & Cukup & 1 & 5,56 \\
3 & Kurang & 0 & 0 \\
\hline Jumlah & & 18 & 100 \\
\hline \multicolumn{2}{l}{ Rata-rata Nilai $=7,83$} &
\end{tabular}

Rata-rata Nilai $=7,83$

Sumber : Data Primer tahun 2020

Berdasarkan tabel 2 dapat diketahui bahwa setelah responden diberikan Pendidikan Kesehatan tentang KB dalam keperawatan Islami paling banyak mempunyai pengetahuan dengan kategori baik yaitu 17 orang $(94,44 \%)$ dan tidak ada yang mempunyai pengetahuan dengan kategori kurang (0\%). Responden memiliki rata-rata nilai pengetahuan 7,83.

\section{2) Pembahasan}

Dari hasil pelaksanaan pengabdian didapatkan data bahwa terjadi peningkatan pengetahuan yang signifikan yaitu kategori baik sebelum intervensi pendidikan kesehatan sebanyak 0 orang $(0 \%)$ dan kategori baik setelah dilakukan intervensi pendidikan kesehatan sebanyak 17 orang $(94,44 \%)$. Terdapat kenaikan jumlah peserta yang memiliki pengetahuan dengan kategori baik yaitu sebanyak 17 orang. Memiliki selisih rata-rata pre dan post test nilai pengetahuan sebanyak 3,33.

Kurangnya pengetahuan wanita tentang KD dalam hukum Islam, dapat menyebabkan seseorang akan ragu-ragu dalam memntukan boleh tidaknya mengikuti program KB. Padahal tujuan KB diantaranya yaitu menyiapkan kondisi ibu dan memberikan asuhan yang baik kepada anak yang sudah dilahirkan. Dengan demikian tidak muncul suatu respon dalam bentuk sikap yang mendukung dilakukannya program KB. Tidak munculnya sikap yang mendukung terhadap $\mathrm{KB}$, akhirnya tidak menjadi peserta $\mathrm{KB}$, sehingga tidak upaya pencegahan terhadap risiko komplikasi kehamilan yang dapat meningkatkan AKI dan AKB.

Pendidikan kesehatan merupakan salah satu faktor untuk meningkatkan perilaku kesehatan yang baik. Hasil pengabdian menunjukkan terdapat kategori kurang sebelum dilakukan pendidikan kesehatan. Hal ini dimungkinkan karena pengetahuan tentang hukum KB dalam Islam yang bertujuan untuk menunda kehamilan belum pernah diberikan oleh tim pengabdian atau penyuluh kesehatan yang lain. Pengetahuan menjadi baik jika seseorang 
mendapatkan informasi, dimana informasi bisa didapatkan dengan pendidikan kesehatan. Pendidikan kesehatan merupakan suatu kegiatan atau usaha untuk menyampaikan informasi kesehatan kepada individu, kelompok ataupun masyarakat, sehingga dapat memperoleh pengetahuan kesehatan yang lebih baik dan dapat berpengaruh terhadap perilakunya (Notoatmodjo, 2012); (Notoatmodjo, 2020).

\section{KESIMPULAN DAN SARAN}

Kesimpulan kegiatan pengabdian ini adalah:

1) Terjadi peningkatan pengetahuan Ibu dan Kader tentang $\mathrm{KB}$ dalam perspektif keperawatan Islam/hukum Islam sebagai upaya menekan risiko kehamilan.

2) Perlu memotivasi kader untuk melakukan kunjungan rumah kepada PUS/WUS untuk menjadi akseptor KB sesuai dengan perencanaan dalam keluarganya.

\section{DAFTAR PUSTAKA}

BKKBN. (2019). Laporan Kinerja BKKBN Jateng. BKKBN Jawa Tengah. https://www.bkkbn.go.id/po-content/uploads/LKIP_JATENG_2019.pdf

Kemenkes RI. (2015). Infodatin. Kementerian Kesehatan RI.

Kemenkes RI. (2019). Profil Kesehatan Indonesia Tahun 2018. Kementerian Kesehatan RI.

Notoatmodjo, S. (2012). Pendidikan dan Perilaku Kesehatan. Rineka Cipta.

Notoatmodjo, S. (2020). Promosi Kesehatan: Teori dan Aplikasi. Rineka Cipta.

Rismoko, A. (2019). Grafik AKI dan AKB Jateng Terus Menurun. https://www.ayosemarang.com/read/2019/03/26/38510/grafik-aki-dan-akb-jateng-terusmenurun

Salengke, H. H. (2019). Angka Kelahiran Ditargetkan Turun Jadi 21 Anak Per Perempuan. Mediaindonesia.Com. https://mediaindonesia.com/read/detail/245300-angka-kelahiranditargetkan-turun-jadi-21-anak-per-perempuan Haufan Hasyim Salengke 2019

Susanto, R. (2019). Kematian Bayi 2019 di Cilacap Naik. Gatra.Com. https://www.gatra.com/detail/news/461462/kesehatan/kematian-bayi-2019-di-cilacapnaik

Susiana, S. (2019). Program Keluarga Harapan dan Penurunan Angka Kematian Ibu (Studi di Provinsi Jambi dan Provinsi Kalimantan Selatan). Jurnal Aspirasi, Vol. 10(No. 1), 19-31. https://doi.org/DOI: 10.22212/aspirasi.v10i1.1107

Utami, S. H. (2019). Jarak Hamil Terlalu Dekat Usai Melahirkan, Ibu Harus Waspada 3 Hal Ini. https://www.suara.com/health/2019/06/27/132000/jarak-hamil-terlalu-dekat-usaimelahirkan-ibu-harus-waspada-3-hal-ini?page=all 